\title{
Bisphenol A exposure promotes HTR-8/SVneo cell migration and impairs mouse placentation involving upregulation of integrin- $\beta 1$ and MMP-9 and stimulation of MAPK and PI3K signaling pathways
}

\author{
Xi Lan ${ }^{1}$, Li-Juan Fu ${ }^{1,2}$, Jun Zhang ${ }^{3}$, Xue-Qing Liu ${ }^{1}$, Hui-Jie Zhang ${ }^{4}$, Xue Zhang ${ }^{1}$, \\ Ming-Fu Ma ${ }^{5}$, Xue-Mei Chen ${ }^{1}$, Jun-Lin $\mathrm{He}^{1}$, Lian-Bing $\mathrm{Li}^{5}$, Ying-Xiong Wang ${ }^{1}$ and \\ Yu-Bin Ding ${ }^{1}$ \\ ${ }^{1}$ Department of Reproductive Biology, School of Public Health, Chongqing Medical University, Chongqing, 400016, P.R. China \\ ${ }^{2}$ Department of Immunology, School of Medicine, University of Pittsburgh, Pittsburgh, Pennsylvania, 15260, USA \\ ${ }^{3}$ Center of Molecular Diagnostic Medicine, Life Science Institute, Chongqing Medical University, Chongqing, 400016, P.R. China \\ ${ }^{4}$ Ministry of Education Key Laboratory of Diagnostic Medicine, College of Laboratory Medicine, Chongqing Medical University, \\ Chongqing, 400016, P.R. China \\ ${ }^{5}$ The Key Laboratory of Birth Defects and Reproductive Health of the National Health and Family Planning Commission, \\ Chongqing Population and Family Planning Science and Technology Research Institute, Chongqing, 401147, P.R. China
}

Correspondence to: Yu-Bin Ding, email: 178384198@qq.com

Keywords: bisphenol A, extravillous trophoblasts, cell migration, placentation, MAPK/PI3K signaling pathway

Received: September 28, $2016 \quad$ Accepted: April 19, $2017 \quad$ Published: May 16, 2017

Copyright: Lan et al. This is an open-access article distributed under the terms of the Creative Commons Attribution License 3.0 (CC BY 3.0), which permits unrestricted use, distribution, and reproduction in any medium, provided the original author and source are credited.

\section{ABSTRACT}

In this study, we investigated the effect of Bisphenol A (BPA), an endocrine-disrupting chemical, on the migration of human trophoblasts and mouse placentation by using the primary extravillous trophoblast (EVT) and its cell line HTR-8/SVneo, villous explant cultures, and pregnant mice. BPA increased EVT motility and the outgrowth of villous explants in a dose-dependent manner. BPA also increased the protein levels of integrin- $\beta 1$ and matrix metalloproteinase (MMP)-9 in human EVTs. Low-dose BPA ( $\leq 50 \mathrm{mg}$ ) increased the protein levels of MMP- 9 and MMP- 2 as well as integrin- $\beta 1$ and integrin-a5 in mouse placenta and decreased the proportion of the labyrinth and spongiotrophoblast layers. Inhibitors of mitogen-activated protein kinase (MAPK) U0126 and phosphatidylinositol3-kinases (PI3K) LY294002 reversed the protein levels of integrin- $\beta 1$ and MMP-9 as well as the migratory ability induced by BPA. In conclusion, these results indicated that BPA can enhance trophoblast migration and impair placentation in mice by a mechanism involving upregulation of integrin(s) and $M M P(s)$ as well as the stimulation of MAPK and PI3K/Akt (protein kinase B) signaling pathways.

\section{INTRODUCTION}

Bisphenol A (BPA) is an endocrine-disrupting chemical that is used extensively in the production of polycarbonate plastics and epoxy resins. The general population, including women of reproductive age and pregnant women, is exposed to BPA in daily life [1]. Contamination by this chemical can occur, for example, through the consumer's skin or by ingestion of personal care products [2]. Adverse effects of BPA on reproductive outcomes and early development are possible [3]. It has been suggested that exposure to BPA may be a detrimental factor related to a decline in female fertility [4]. Oogenesis impairment, reduced embryo implantation sites, and even sociosexual behavioral changes in mice and rats were observed after BPA exposure [5-8]. BPA also leads to compromised in vitro decidualization in human endometrial stromal cells [9].

BPA may interfere with the biological function of trophoblast and placenta [10]. In vitro studies show that BPA exposure severely disrupts the expression of human placental genes and of several prominent 
placental hormones/factors in trophoblast cells isolated from human placentas at term [11]. Trophoblast cell invasion, proliferation, apoptosis and differentiation were significantly altered upon BPA exposure [12-16]. Moreover, the rapid movement of BPA was observed across the term placenta and BeWo cell line monolayer [17]. Mediated by P-glycoprotein and the ATP-binding cassette sub-family G member 2 (ABCG2) transporter proteins, BPA may stimulate drug efflux in human placenta $[18,19]$. In mouse and rat in vivo studies, BPA disrupts placental development and leads to degenerative changes, which lead to reproductive disorders [20-23].

The migration of trophoblast is of profound significance during embryo implantation and early embryonic development [24-27]. Excessive trophoblast invasion is involved with placenta accreta, increta, percreta or choriocarcinoma [28]. In this study, we aimed to characterize the effects of BPA on trophoblast motility and placentation as well as their possible mechanisms, which may present insights into reproductive toxicity of BPA.

\section{RESULTS}

\section{HTR-8/SVneo cell proliferation was not changed by BPA treatment}

The effect of BPA on the viability of the EVT cell line HTR-8/SVneo was determined by flow cytometry
(Supplementary Figure 1). No significant difference in cytotoxicity was observed when cells were treated with $10^{-7}-5 \times 10^{-5} \mathrm{M}$ BPA. The protein level of proliferating cell nuclear antigen (PCNA), a cell proliferation marker, did not change after BPA treatment (Figure 1A). In addition, flow cytometry and 5-ethynyl-2'-deoxyutidine (EdU) assay confirmed that exposure to the above concentrations of BPA had no significant impact on cell proliferation of the HTR-8/ SVneo cell line (Figure 1B, 1C; Supplementary Figure 2).

\section{BPA increased the motility of HTR-8/SVneo cells}

A monolayer scratch assay was performed to assess the ability of HTR-8/SVneo cells to migrate away from a confluent monolayer. The distance (in micrometers) traveled by the cells to populate the cell-free gap created by the scratch wound was calculated and plotted. Higher concentrations of BPA increased the migratory ability of the cells toward the scratched area compared to that obtained with untreated controls within $24 \mathrm{~h}$ and $48 \mathrm{~h}$ of scratching (Figure 2A). Similar to the results of the wound assay, the migratory ability of HTR-8/SVneo cells, assessed by the Transwell assay, was also altered in response to BPA (Figure 2B).

\section{BPA induced the migration and outgrowth of villous explants}

To further confirm the impact of BPA on trophoblast migration in vivo, each explant was obtained from a

A
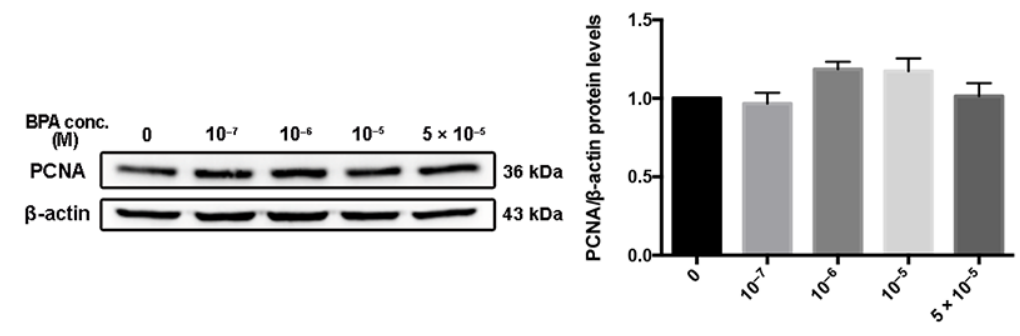

Concentration of BPA (M)

C

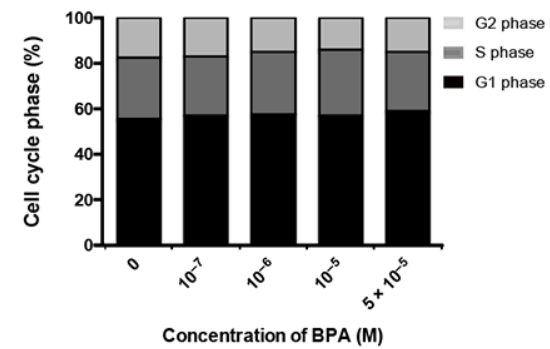

Figure 1: HTR-8/SVneo cell proliferation after BPA treatment. (A) Western blot detection of PCNA in HTR-8/SVneo cells treated with different doses of BPA for $48 \mathrm{~h}$. $\beta$-actin was used as the loading control. The bands were quantified, normalized by $\beta$-actin, and presented relative to control (1.0) as means \pm SEM. (B) Proliferative cells detection by EdU assay. The proliferation rate was quantified by counting the number of EdU-positive cells in each of five randomly selected fields. (C) Flow cytometry evaluation of cell cycle and the percentage of cells in G1, G2, and S phase. 
single placenta and separated into two groups which were treated with BPA $\left(5 \times 10^{-5} \mathrm{M}\right)$ or vehicle control. Bright field images showed that there were significantly more trophoblast cells in the outgrowth area from villous tip in BPA-treated explant cultures compared to that observed in the controls. The average outgrowth lengths were 0.54 $\mathrm{mm}$ and $0.91 \mathrm{~mm}$ in explants treated for $48 \mathrm{~h}$ and $72 \mathrm{~h}$ with BPA, respectively; while the average outgrowth lengths were $0.45 \mathrm{~mm}$ and $0.67 \mathrm{~mm}$ at $48 \mathrm{~h}$ and $72 \mathrm{~h}$, respectively, in the control explants (Figure $3 \mathrm{~A}$ ). The ratio of the outgrowth area compared to the total area of the explant in BPA-treated group was $82.3 \%$ and $87.5 \%$ at 48 $\mathrm{h}$ and $72 \mathrm{~h}$, respectively; the ratio was $67.0 \%$ and $80.6 \%$ in the control at $48 \mathrm{~h}$ and $72 \mathrm{~h}$, respectively (Figure 3A). Similarly, the results showed a dose-dependent increase in migration of primary EVT cells after exposure to BPA (Figure 3B).

\section{Protein level of MMP-9 after BPA exposure and the effect of MMP-9 on cell migration}

BPA $\left(5 \times 10^{-5} \mathrm{M}\right)$ increased the protein level of MMP-9 to $246.3 \%$ of that of the control; however, the level of matrix metalloproteinase (MMP)-2 did not change. In addition, the protein level of TIMP-3 decreased in a dosedependent manner following BPA exposure (Figure 4A). The protein levels of both MMP-9 and MMP-2 increased after BPA treatment of primary EVTs (Supplementary Figure 3A). The effects of MMP-9 inhibitor SC-311437 on cell viability and $M M P-9$ expression were assessed prior to the migration assay (Figure 4B, 4C, Supplementary Figure 4). The protein level of MMP-9 in cells co-treated with BPA and SC-311437 was weaker than that treated with BPA alone (Figure 4C). The number of cells that migrated across the Transwell insert membrane in BPA-
A

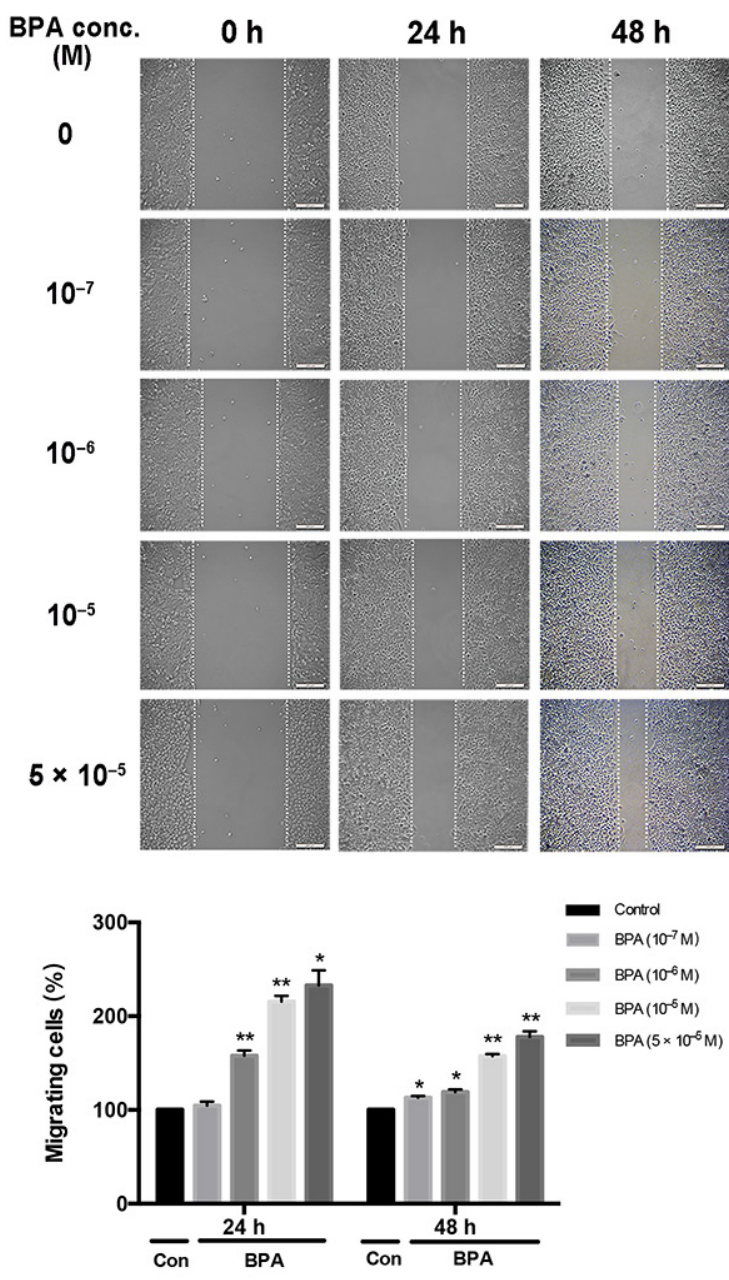

B
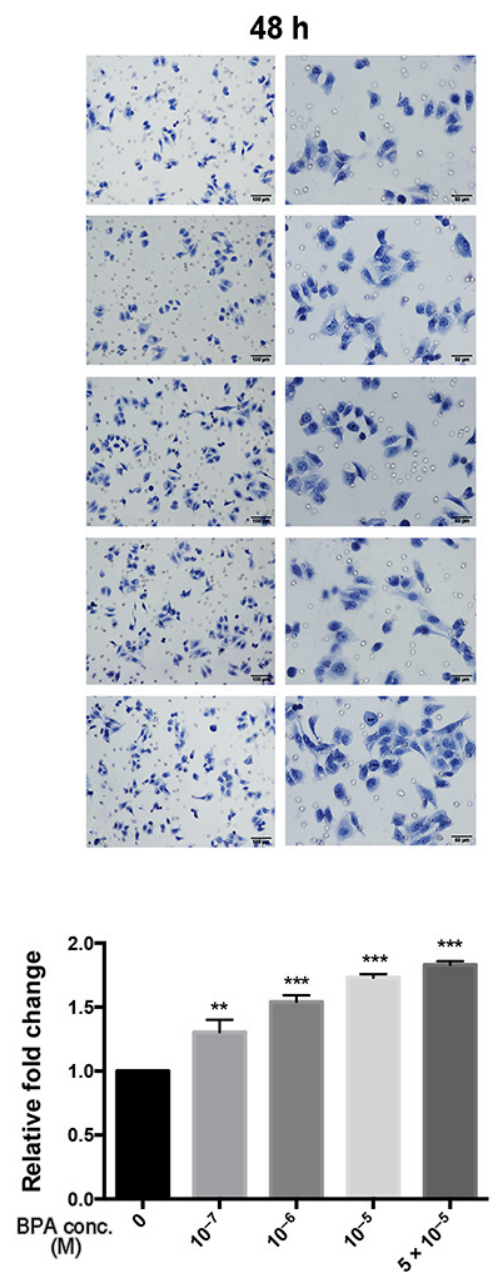

Figure 2: Migration of HTR-8/SVneo cells treated with different concentrations of BPA. Scratch and Transwell assays were performed after $48 \mathrm{~h}$ treatment of BPA. (A) Migration of cells by scratch assay. Significant differences between BPA-treated and control groups are indicated $\left(* P<0.05,{ }^{*} P<0.01\right)$. Scale bar, $200 \mu \mathrm{m}$. (B) Migration of cells by Transwell assay. $* * P<0.01, * * * P<0.001$. Scale bar, $100 \mu \mathrm{m}$ or $50 \mu \mathrm{m}$. 
and SC-311437-treated cells was reduced by $55.65 \%$ of that of the BPA-treated cells (Figure 5F).

\section{Integrin- $\beta 1$ level after BPA exposure and the effect of integrin- $\beta 1$ on cell migration}

The mRNA and protein levels of integrin- $\beta 1$, an extracellular matrix (ECM) transmembrane receptor, increased in HTR-8/SVneo cells upon BPA treatment (Figure 5A, 5B). Stronger integrin- $\beta 1$ intensity was shown in BPA exposed cells than those in the control (Figure $5 C)$. However, the level of integrin- $\alpha 5$, another ECM transmembrane receptor, was not altered in HTR-8/SVneo cells after BPA exposure (Supplementary Figure 5). The upregulation of integrin- $\beta 1$ and integrin- $\alpha 5$ was also observed in primary EVT cells (Supplementary Figure 3B). si-ITGB1 knockdown efficiency was verified by western blot and RT-qPCR (Figure 5D, 5E). It showed that both cell migration and the protein level of integrin- $\beta 1$ in cells co-treated with BPA and si-ITGB1 were significantly reduced compared to those treated with BPA alone (Figure $5 \mathrm{E}, 5 \mathrm{~F})$.

\section{BPA treatment did not change mesenchymal and epithelial biomarker levels}

BPA exposure did not change the protein and mRNA levels of mesenchymal markers vimentin or $\mathrm{N}$-cadherin (encoded by $\mathrm{CDH} 2$ ) in the HTR-8/SVneo cell line (Figure 6A-6C). Immunofluorescence staining confirmed these results (Figure 6D). Similarly, the protein level of N-cadherin and epithelial marker E-cadherin did not change in primary EVTs exposed to BPA (Supplementary Figure 3C). Since the HTR-8/SVneo cell line dose not

A
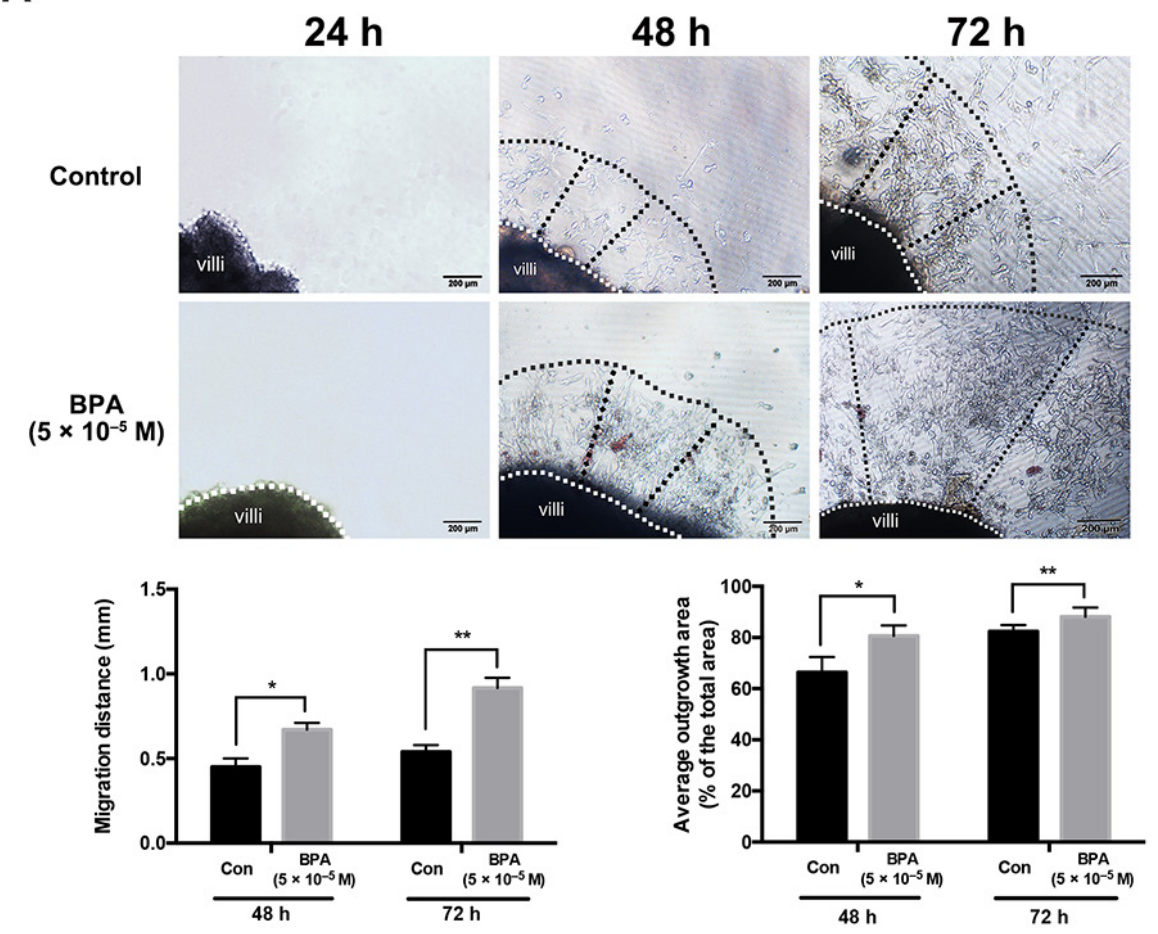

B
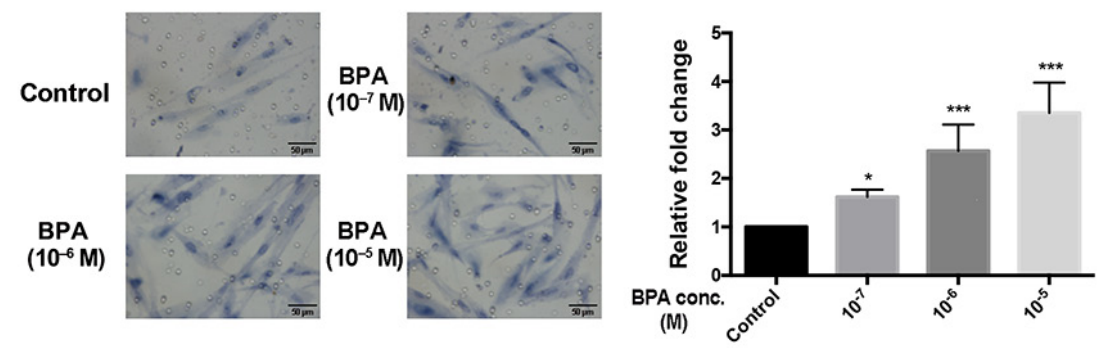

Figure 3: Migration and outgrowth of the trophoblast from explanted first trimester placental villi in the presence and absence of BPA. (A) Villi were treated with BPA for $72 \mathrm{~h}$. Dashed lines represent the column base (white) and invasive extremity (black). The Matrigel explant assay was performed in duplicate. ${ }^{*} P<0.05,{ }^{*} P<0.01$. Scale bar, $200 \mu \mathrm{m}$. (B) Transwell migration assay detection the effect of BPA on primary EVTs migration. The primary EVTs were treated with BPA at the concentrations of $10^{-7} \mathrm{M}, 10^{-6}$ and $10^{-5} \mathrm{M}$. $* P<0.05, * * * P<0.001$. Scale bar, $50 \mu \mathrm{m}$. 
express E-cadherin and primary EVTs do not produce vimentin, we did not detect changes in their expression after exposure to BPA.

\section{MAPK and PI3K signaling pathways participated in BPA-stimulated levels of integrin- $\beta 1$ and MMP-9 and cell migration}

The phosphorylation of protein kinase B (Akt, Thr308 and Ser73) and ERK1/2 increased, integrin- $\beta 1$ and MMP-9 were upregulated, and TIMP-3 was downregulated in BPAtreated HTR-8/SVneo cells compared to those in control cells (Figure 7A). In addition, treatment with the extracellular signal-regulated kinase (ERK1/2) inhibitor U0126 or the PI3K inhibitor LY294002 for $24 \mathrm{~h}$ abolished the BPAinduced phosphorylation of ERK and Akt, respectively (Figure 7A). The migration of HTR-8/SVneo cells incubated with BPA in the presence or absence of U0126 or LY294002 were also altered accordingly (Figure 7B).

\section{MAPK and PI3K signaling pathways were involved in the upregulation of BPA-induced integrin- $\beta 1$ and integrin- $\alpha 5$ in mouse placentas and impaired placentation}

To avoid any adverse effect of high dose of BPA on blastocyst development and implantation, pregnant mice were administrated with low doses of BPA (5 mg/kg, $10 \mathrm{mg} / \mathrm{kg}$, and $40 \mathrm{mg} / \mathrm{kg}$ ) from E0.5 to E5.5 of pregnancy. The protein levels of integrin- $\beta 1$ and integrin- $\alpha 5$ were remarkably increased in BPA-treated mouse placentas, especially in the labyrinthine layer and the decidua basalis as detected by immunohistochemistry, whereas they were almost undetectable in control mouse placentas (Figure 8A, $8 \mathrm{~B})$. Neither integrin- $\beta 1$ nor integrin- $\alpha 5$ was expressed in the spongiotrophoblast layer of placentas of the two groups. BPA also enhanced the protein levels of MMP9 and MMP-2 in mouse placentas and inhibited the level of TIMP-3 (Figure 8C). Meanwhile, the levels of phosphorylated Akt (Thr308 and Ser473) and ERK also increased after 5 days of treatment with $5 \mathrm{mg} / \mathrm{kg}$ or 40 $\mathrm{mg} / \mathrm{kg}$ BPA (Figure 8F).

The relative proportion of placental labyrinth was lower in mice treated with BPA than that of the controls by E14.5 (Figure 8A, 8B, 8D). The spongiotrophoblastic layer was also reduced in mouse placentas treated with the $10 \mathrm{mg} / \mathrm{kg}$ and $40 \mathrm{mg} / \mathrm{kg}$ BPA compared to that of the controls and the placentas treated with lower dose of BPA ( $5 \mathrm{mg} / \mathrm{kg}$ ). Furthermore, the intervillous spaces in the labyrinth were narrowed and reduced in BPA-treated mice than in the control (Figure 8E, arrows). Glycogenosomes were more frequently noted in the control than in the BPA-treated mice (Figure 8E, arrowheads). Notably, large vacuoles were present in the placentas of mice treated with $10 \mathrm{mg} / \mathrm{kg}$ and $40 \mathrm{mg} / \mathrm{kg}$ BPA (Figure 8A, 8B).

A
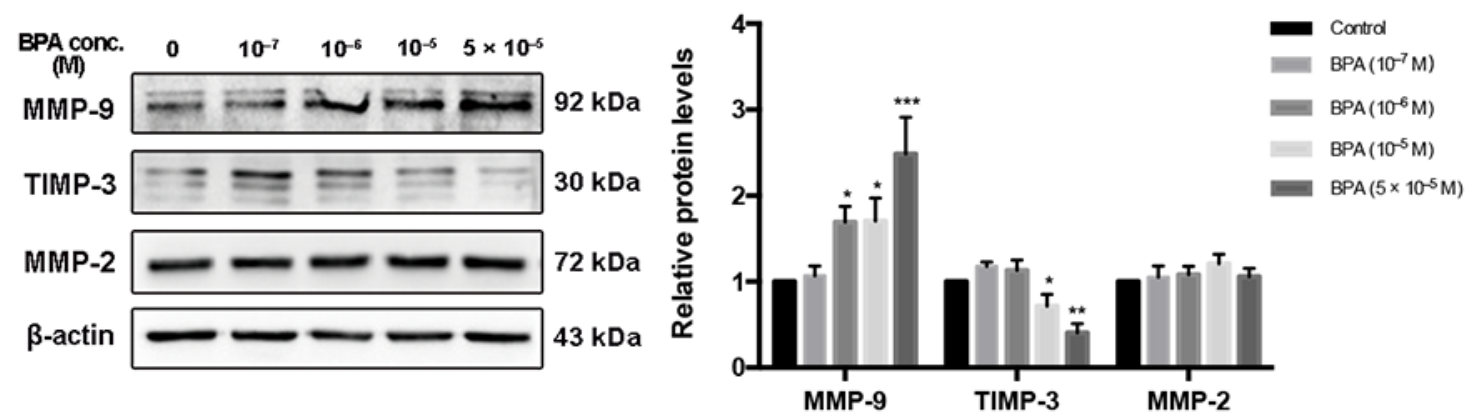

B

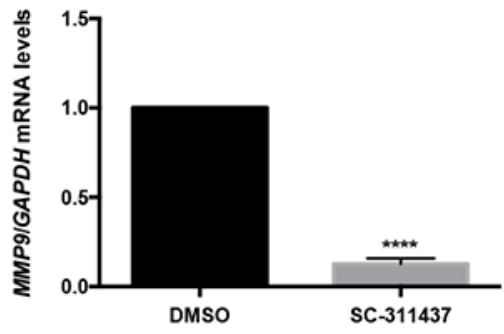

C

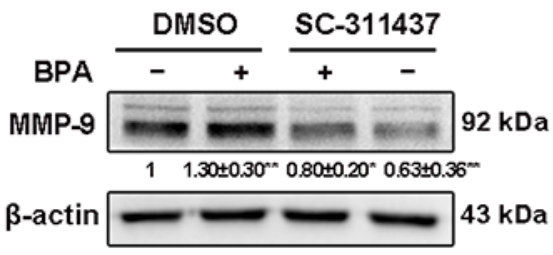

Figure 4: MMP-9, TIMP-3 and MMP-2 expression in HTR-8/SVneo cells exposed to BPA. (A) Western blot analysis of protein levels of MMP-9, TIMP-3 and MMP-2. $* P<0.05$, $* * P<0.01, * * * P<0.001$. (B) RT-qPCR detection of mRNA level of MMP-9 after inhibition by $5 \mu \mathrm{M} \mathrm{SC}-311437$ for $24 \mathrm{~h}$. $* * * * P<0.0001$. (C) Protein level of MMP-9 after treatment with BPA $\left(10^{-6} \mathrm{M}\right)$ together with or without SC-311437. $* P<0.05, * * P<0.01$. 


\section{DISCUSSION}

BPA may impair EVT cell proliferation, migration, and invasion, key processes for placentation and pregnancy in mammals [16]. We found that BPA-enhanced migration of EVT in a dose-dependent manner. BPA exposure also stimulates migration of several cancer cell lines in vitro [33-37]. However, these results are inconsistent with the finding that BPA inhibits the migratory and invasive abilities of HTR-8/SVneo cells at concentrations of $10^{-11}$ $\mathrm{M}$ to $10^{-7} \mathrm{M}[16]$. We speculate that cell culture conditions, such as medium composition, pre-treatment of Transwell chamber with collagen and the recovery time after BPA removal, may interfere with cell migration in these studies.

MMP-9, an autocrine factor that localizes primarily to EVT cells at 6-8 weeks of human gestation, regulates trophoblast invasion and migration by degrading ECM
$[28,38,39]$. BPA exposure induces expression of $M M P \mathrm{~s}$ and cell migration in several cancer cell types $[33,37]$. We confirmed that MMP-9 and MMP-2 were involved in BPAinduced EVTs migration. Previous studies have shown that MMP-9 is the effector molecule of ECM adhesion receptor integrin- $\beta 1[40,41]$. Our study revealed that BPA exposure increased the level of integrin- $\beta 1$ and integrin- $\alpha 5$ in EVT cells. Results obtained from ITGBI (encodes integrin- $\beta 1$ ) knockdown and MMP-9 inhibition assays further indicated that MMP-9 and integrin- $\beta 1$ might be the targets of BPAinduced migration. Similar inducible effect of BPA was also observed in a normal colon epithelial cell line [42].

Since, ERK and Akt are downstream effectors of integrins [43], we evaluated the effect of BPA on the activation of the MAPK and PI3K/Akt signaling pathways. Phosphorylation of ERK1/2 and Akt increased in HTR-8/SVneo cells after BPA exposure. The inhibitors

A
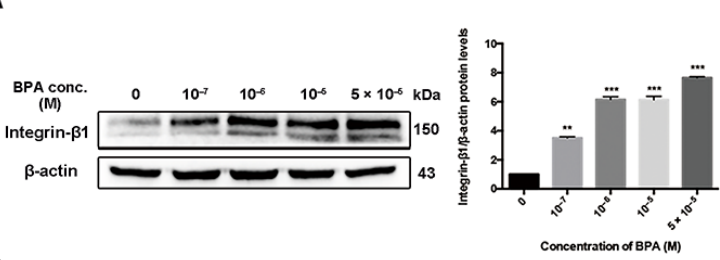

C
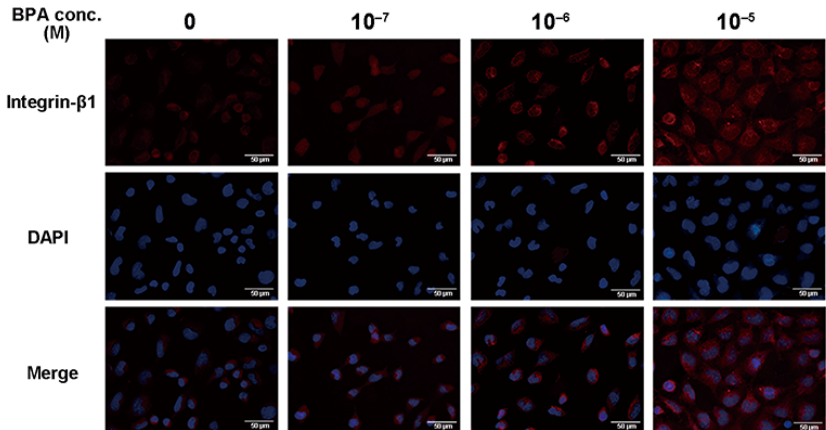

$5 \times 10^{-5}$
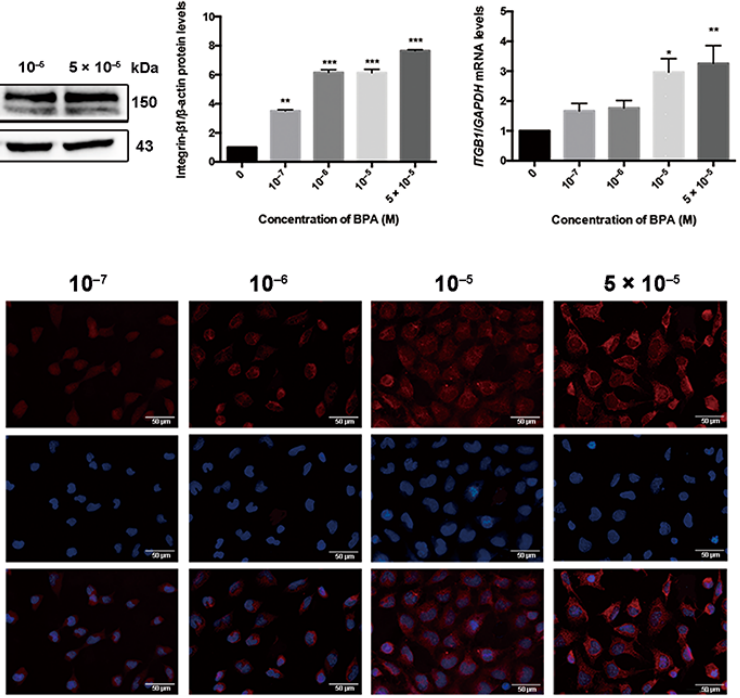

D

$\mathbf{F}$
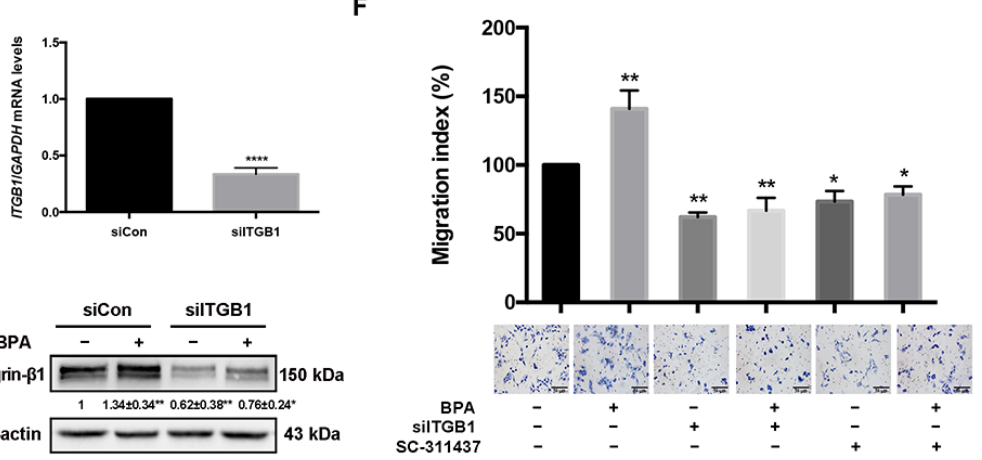

Figure 5: Integrin-ß1 (ITGB1) expression in HTR-8/SVneo cells treated with BPA. (A, B) ITGB1 protein and mRNA levels in HTR-8/SVneo cells treated with BPA were determined by western blot (A) and RT-qPCR (B). GAPDH was used as control for RT-qPCR and $\beta$-actin for western blot. $* P<0.05, * * P<0.01, * * * P<0.001$. (C) Immunofluorescence staining of integrin- $\beta 1$ in HTR-8/SVneo cells treated with BPA. Blue indicates DAPI staining, whereas red (Cy5) indicates integrin- $\beta 1$. Scale bar, $50 \mu \mathrm{m}$. (D) RT-qPCR detection of mRNA level of integrin- $\beta 1$ in cells transfected by $2 \mu \mathrm{M}$ siRNA for $48 \mathrm{~h}$. $* * * * P<0.0001$. (E) Protein level of integrin- $\beta 1$ after treatment with BPA $\left(10^{-6} \mathrm{M}\right)$ with or without siRNA transfection. ${ }^{*} P<0.05, * * P<0.01$. (F) Transwell assay detection of HTR-8/SVneo cell migration co-treated with si-ITGB1 and MMP-9 inhibitor SC-311437. $* P<0.05, * * P<0.01$. Scale bar, $100 \mu \mathrm{m}$. 
of the MAPK and PI3K signaling pathways blocked BPAstimulated cell migration and protein levels of integrin- $\beta 1$ and MMP-9. Our results suggest that MAPK and PI3K signaling pathways might be involved in BPA-mediated stimulation of EVT cell migration in vitro.

BPA exerts detrimental effects on placentation in mice and rats [20, 22, 44]. "Low doses" of BPA (below $50 \mathrm{mg} / \mathrm{kg}$ body weight/day), defined by the National Institute for Environmental Health Sciences [45], were used in the present study. We showed that low-dose BPA increased integrin- $\beta 1$ and integrin- $\alpha 5$ protein levels in the labyrinthine and decidua basalis layers. BPA exposure reduced the thickness of the labyrinthine and the spongiotrophoblastic layers, and increased the number of vacuoles above the spongiotrophoblasts. This was similar to Tait et al.'s findings that orally administrated BPA (50 $\mathrm{mg} / \mathrm{kg}$, from E1 to E11) led to increased vacuolization and reduction of spongiotrophoblast layer on E12 in CD-1 mice [23].

Blood vessels come to occupy the villous space in mice with the development of the villi [46]. The intervillous spaces within the labyrinth normally diminish in size as gestation proceeds as a consequence of the increasing density of the trophoblast branches [47]. In gene mutant mice with reduced branching and extension of the trophoblast villi, placentas attempted to compensate for the reduced nutrient transport by increasing fetal capillary density [46]. Consistent with the results of Tachibana et al.'s study [22], we noticed that the intervillous space in the labyrinth layer narrowed in the presence of BPA. Cross et al. suggested that vascular development was not the driving force behind labyrinth development in mice, but was the initiating molecular event in chorionic trophoblasts elucidating the scenario of labyrinth development [48].

During later periods of gestation in mouse, glycogen trophoblast cells differentiate within the spongiotrophoblast layer and subsequently diffusely invade the uterine wall. Mouse trophoblast giant cells (TGCs) are analogous to human EVTs, which ultimately differentiate into the polyploid giant cells of the placenta and exert their migratory and invasive properties [46]. We observed that the number of glycogenosomes within the TGCs was reduced in BPA-treated mice, which is similar with Tait et al.'s finding regarding depletion of glycogen storage [23].

A

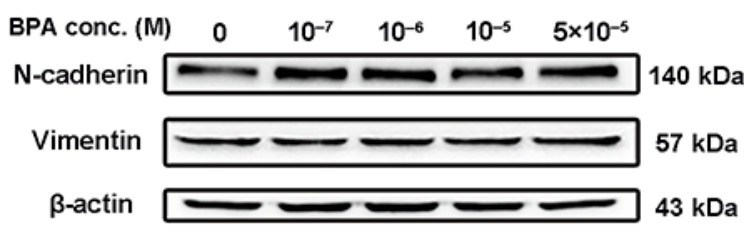

BPA conc.

(M)
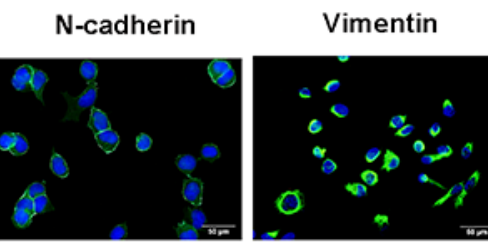

B
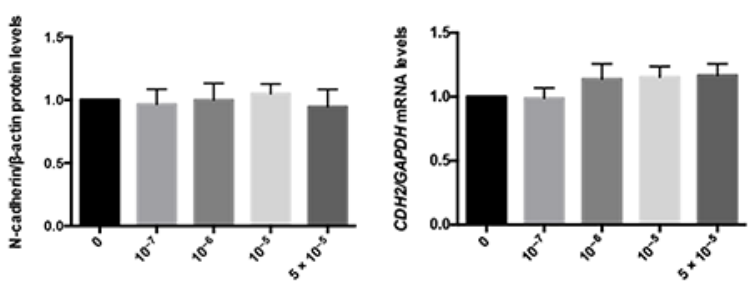

$10^{-7}$
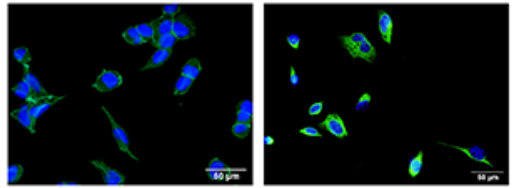

C

Concentration of BPA (M)
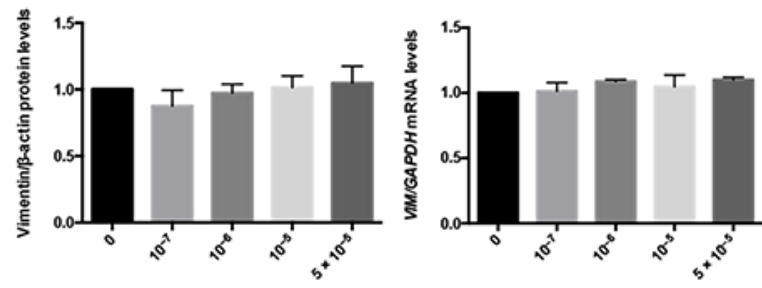

Concentration of BPA (M)
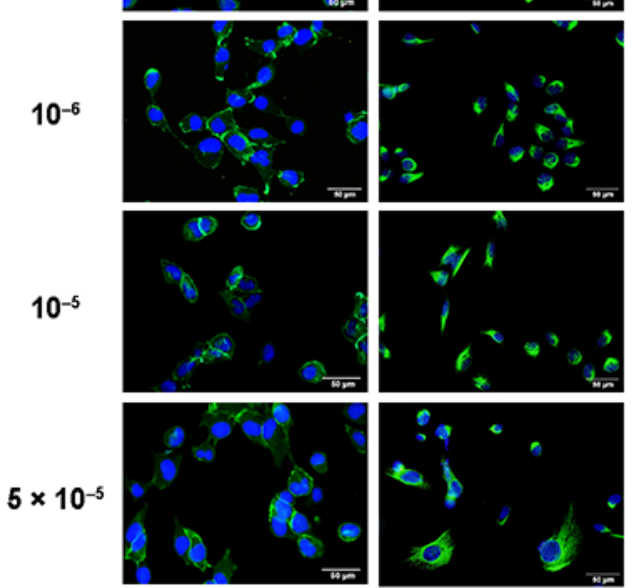

Figure 6: Expression of $\boldsymbol{C D H} 2$ and $V I M$ in HTR-8/SVneo cells exposed to BPA. (A-C) Protein (A, B) and mRNA (C) levels of N-cadherin (encoded by $\mathrm{CDH} 2$ ) and vimentin (encoded by VIM) in HTR-8/SVneo cells treated with BPA as determined by western blot and RT-qPCR, respectively. (D) Immunofluorescence intensity of N-cadherin and vimentin in cells treated with different concentrations of BPA. Blue indicates DAPI staining, whereas green (FITC) indicates N-cadherin and vimentin. Scale bar, $50 \mu \mathrm{m}$. 
A
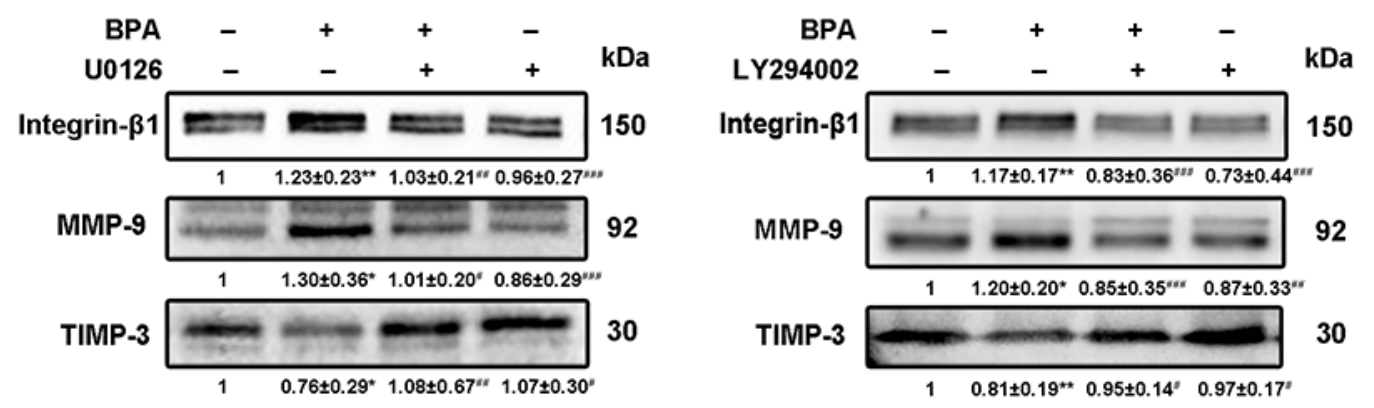

TIMP-3
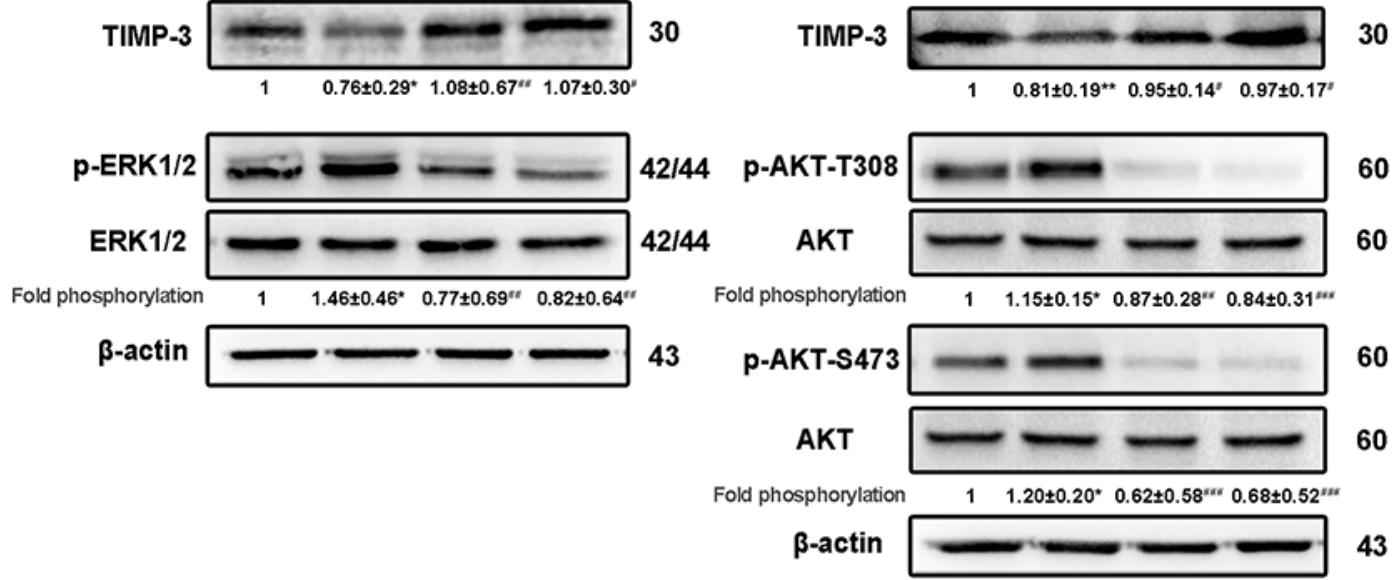

B
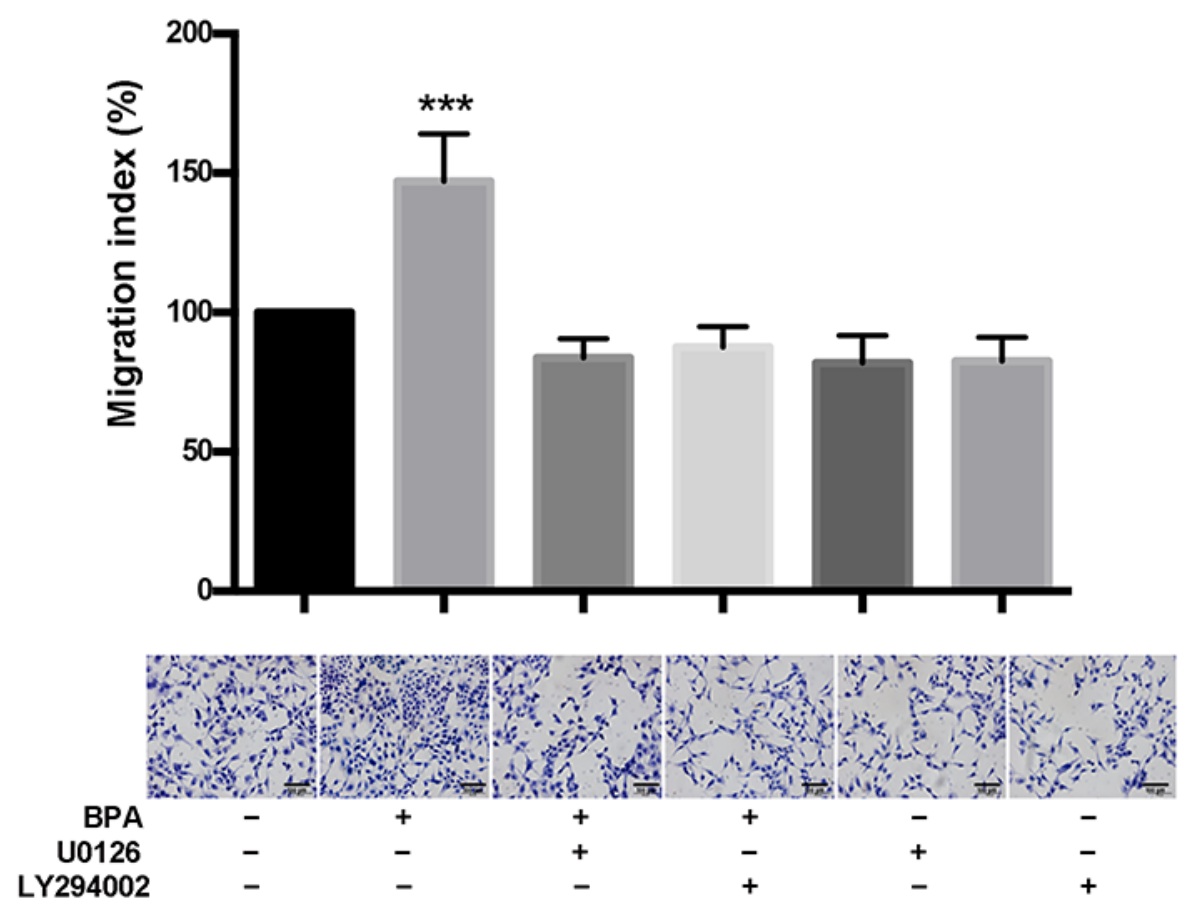

Figure 7: BPA-stimulated HTR-8/SVneo cell migration, MMP-9 and integrin- $\beta 1$ upregulation, as well as MAPK and PI3K signaling pathways activation. (A) Western blot analyses of integrin- $\beta 1$, MMP-9, and TIMP-3 protein levels and phosphorylation levels of ERK and Akt (p-Akt T308 and p-Akt S473) in HTR-8/SVneo cells exposed to BPA for $48 \mathrm{~h}$ with or without addition of U0126 $(10 \mu \mathrm{M})$ and LY294002 $(5 \mu \mathrm{M})$ for $24 \mathrm{~h} .{ }^{*} P<0.05,{ }^{* *} P<0.01,{ }^{* * *} P<0.001 .{ }^{*} P<0.05$ compared with vehicle control group; ${ }^{*} P<0.05$ compared with the BPA treatment group. (B) Transwell assay detection of the migration of HTR-8/SVneo cells treated with BPA $\left(10^{-6} \mathrm{M}\right)$ and/or U0126 or LY294002. The Transwell assay was performed for six times. ${ }^{* * *} P<0.001$. Scale bar, $100 \mu \mathrm{m}$. 
A

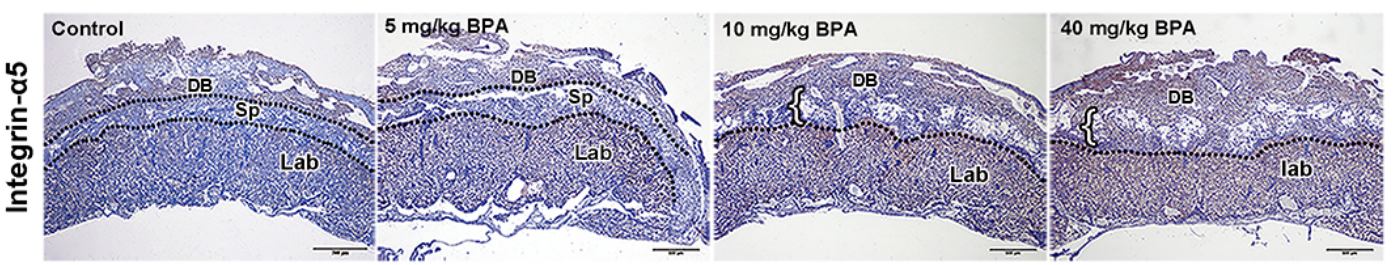

B

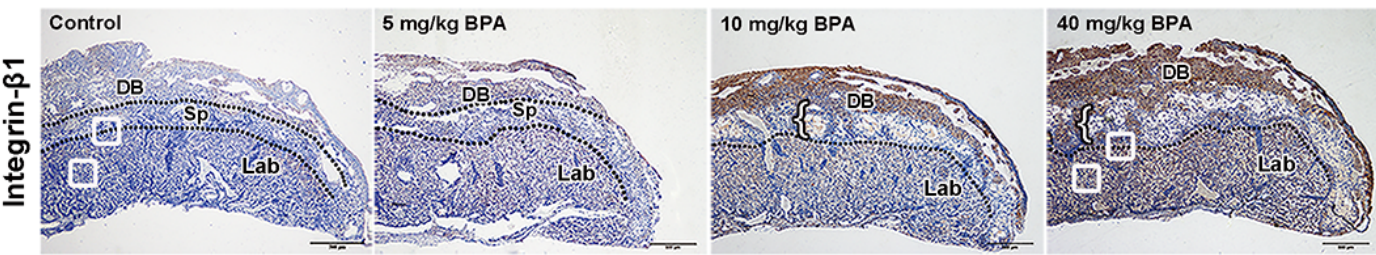

C

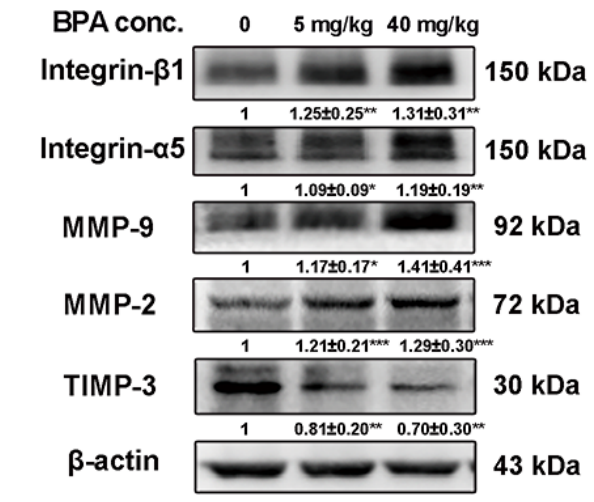

D

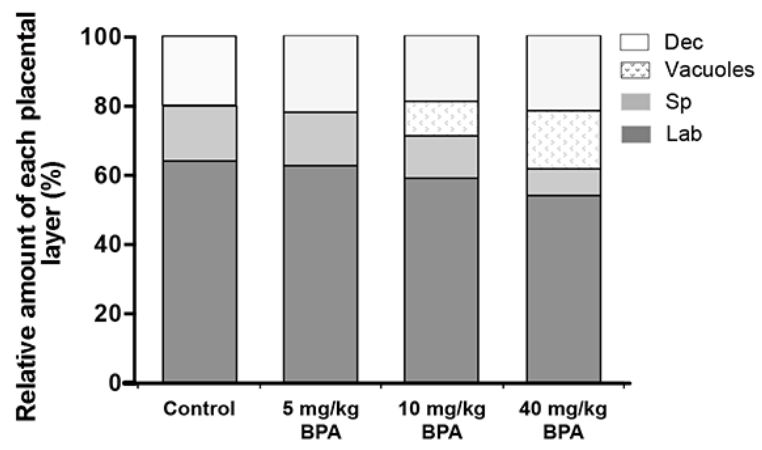

$E$

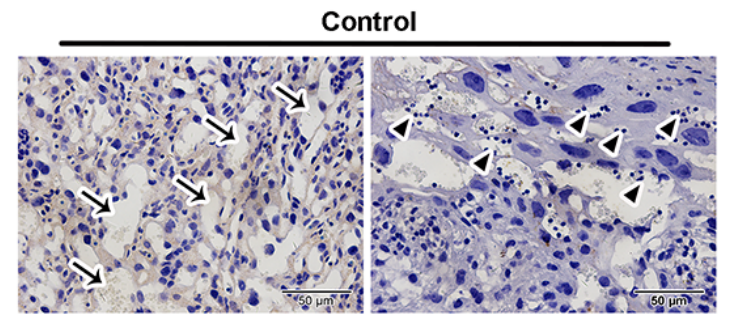

$40 \mathrm{mg} / \mathrm{kg}$ BPA

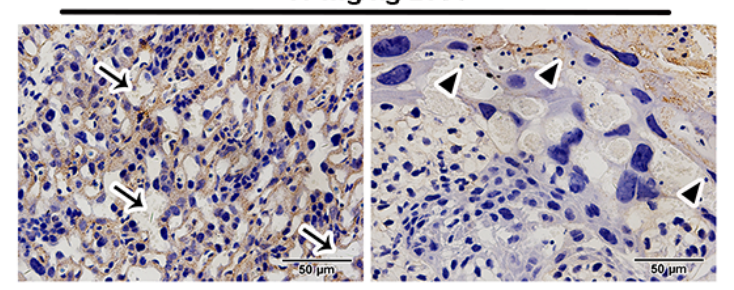

$\mathbf{F}$

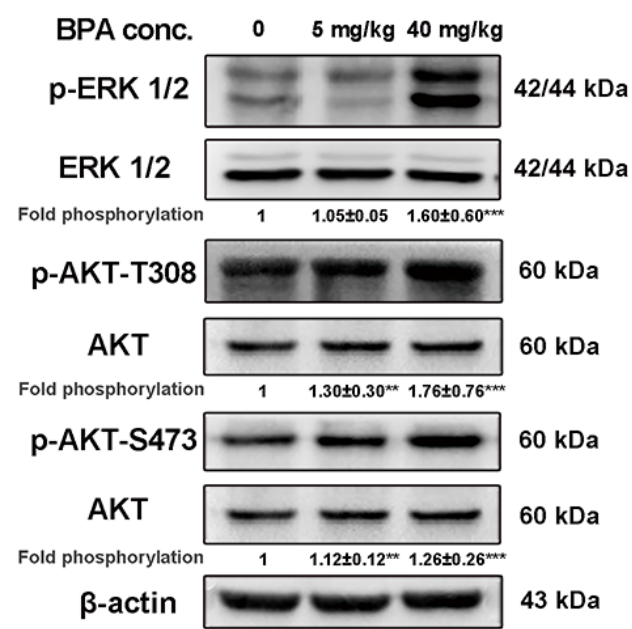

Figure 8: BPA-induced impaired placentation, upregulation of integrins and MMPs as well as activation of MAPK and PI3K signaling pathways in mice. (A, B) Immunohistochemical detection of integrin- $\alpha 5$ (A) and integrin- $\beta 1$ (B) in mouse placentas on E14.5. Mice were exposed to BPA from E0.5 to E5.5 of pregnancy. Black dotted lines indicate the boundaries of the placental layers. Brown staining indicates positive staining. DB, decidua basalis; Sp, spongiotrophoblast layer; Lab, labyrinthine layer. Left brace indicates vacuoles obtained from placentas of mice treated with $10 \mathrm{mg} / \mathrm{kg}$ and $40 \mathrm{mg} / \mathrm{kg}$ BPA. White boxes in the labyrinthine layer in B (control and $40 \mathrm{mg} / \mathrm{kg} \mathrm{BPA}$ ) are enlarged in E. Scale bar, $500 \mu \mathrm{m}$. (C) Western blot analysis of integrin- $\beta 1$, integrin- $\alpha 5$, MMP-9, MMP-2, and TIMP3 in the placenta on E14.5 from mice treated with BPA as in A and B. Values are mean \pm SE. $* P<0.05, * * P<0.01, * * * P<0.001$. (D) Changes in the relative amount of each layer in the E14.5 placenta from mice treated with BPA. (E) BPA-induced morphological changing areas enlarged from Figure 8B. Arrows show the intervillous spaces in the labyrinthine layers in mouse placenta. Arrowheads indicate the glycogensome lining within the trophoblast giant cells. Scale bar, $50 \mu \mathrm{m}$. (F) Analysis of ERK and Akt (T308 and S473) phosphorylation in placentas from mice treated with BPA. Values are mean \pm SE. $* * P<0.01, * * * P<0.001$. 
Table 1: Primers used for RT-qPCR

\begin{tabular}{|c|c|c|c|}
\hline Gene & Accession No. & Primer $\left(5^{\prime}-3^{\prime}\right)$ & $\begin{array}{c}\text { Amplicon } \\
\text { length }\end{array}$ \\
\hline \multirow[t]{2}{*}{$G A P D H$} & NM_002046.5 & Forward CAGGAGGCATTGCTGATGAT & $138 \mathrm{bp}$ \\
\hline & & Reverse GAAGGCTGGGGCTCATTT & \\
\hline \multirow[t]{2}{*}{$I T G B 1$} & NM_033668 & Forward CCTACTTCTGCACGATGTGATG & $128 \mathrm{bp}$ \\
\hline & & Reverse CCTTTGCTACGGTTGGTTACATT & \\
\hline \multirow[t]{2}{*}{$\mathrm{CDH} 2$} & NM_001792 & Forward AGCCAACCTTAACTGAGGAGT & $136 \mathrm{bp}$ \\
\hline & & Reverse GGCAAGTTGATTGGAGGGATG & \\
\hline \multirow[t]{2}{*}{$V I M$} & NM_003380 & Forward GACGCCATCAACACCGAGTT & $238 \mathrm{bp}$ \\
\hline & & Reverse CTTTGTCGTTGGTTAGCTGGT & \\
\hline \multirow[t]{2}{*}{$M M P-9$} & NM_004994 & Forward TGTACCGCTATGGTTACACTCG & $97 \mathrm{bp}$ \\
\hline & & Reverse GGCAGGGACAGTTGCTTCT & \\
\hline
\end{tabular}

Table 2: Sequences of siRNA used for knockdown assay

\begin{tabular}{lll}
\hline Gene & & \multicolumn{1}{c}{ Sequence $\mathbf{( \mathbf { 5 } ^ { \prime } - \mathbf { 3 } ^ { \prime } \mathbf { ) }}$} \\
\hline Scrambled control & Sense & UUCUCCGAACGUGUCACGUTT \\
& Antisense & ACGUGACACGUUCGGAGAATT \\
si-ITGB1 (human) & Sense & GGAGUUUGCUAAAUUUGAATT \\
& Antisense & UUCAAAUUUAGCAAACUCCTT \\
\hline
\end{tabular}

In summary, we found that BPA promotes trophoblast migration and impairs placentation through a mechanism involving the up-regulation of integrin- $\beta 1$ and MMP-9 and activation of the MAPK/ERK and PI3K/Akt signaling pathways in vitro and in vivo. Our results provide new evidence for the effects of BPA exposure on reproductive systems.

\section{MATERIALS AND METHODS}

\section{Cell culture and drug administration}

The EVT cell line HTR-8/SVneo was a kind gift from Dr. Charles Graham [29]. HTR-8/SVneo cells were maintained in Roswell Park Memorial Institute (RPMI) 1640 medium (Life Technologies, Carlsbad, CA, USA) containing $25 \mathrm{mM}$ glucose, $2.05 \mathrm{mM}$ l-glutamine, and antibiotics (100 U/ml penicillin, $100 \mu \mathrm{g} / \mathrm{ml}$ streptomycin) and was supplemented with $10 \%$ fetal bovine serum (FBS). HTR-8/SVneo cells were treated with BPA (Sigma, St. Louis, MO, USA) dissolved in dimethyl sulfoxide (DMSO; Sigma) for $48 \mathrm{~h}$ at concentrations of $10^{-7} \mathrm{M}, 10^{-6}$ $\mathrm{M}, 10^{-5} \mathrm{M}$, and $5 \times 10^{-5} \mathrm{M}$. DMSO was used as vehicle and its concentration in culture medium did not exceed $0.1 \%$. After a 48 -h BPA treatment, the cells were harvested or used for experiments described below. The specific MMP-9 inhibitor SC-311437 (Santa Cruz, CA, USA) was used to repress MMP-9. The selective MAP kinase kinase
(MKK) inhibitor U0126 (Abcam, Cambridge, UK) and the PI3-kinase inhibitor LY294002 (Abcam) were applied to inhibit MAPK and PI3K signaling pathways, respectively.

\section{Animals and drug administration}

Virgin Kunming mice (10- to 12-weeks-old) were obtained from the Laboratory Animal Centre, Chongqing Medical University (Chongqing, China). All experimental procedures were approved by the Ethics Committee of Chongqing Medical University. Mice were housed under a 12-h light and 12-h dark cycle with water and food ad libitum. Females and males were housed separately until mating. The first day of pregnancy (embryonic day E0.5) was defined as the day when a vaginal plug was detected. BPA $(5,10,40 \mathrm{mg} / \mathrm{kg} /$ day $)$ dissolved in corn oil (Sigma) was injected into the mice subcutaneously for 5 days from E0.5 to E5.5. Mice injected with vehicle from E0.5 to E5.5 were used as the controls. Placentas were excised under pentobarbital anesthesia on E14.5. Mean values of the thickness of each placenta layer were calculated using serial section from each of five individuals.

\section{Western blot analysis}

Cells seeded in 24-well plates were lysed in $200 \mu \mathrm{l}$ SDS lysis buffer (Beyotime, Shanghai, China). 
Lysed cells were denatured and boiled at $100^{\circ} \mathrm{C}$ for 10 minutes. Frozen placental samples were homogenised in radio immunoprecipitation assay (RIPA, Beyotime) lysis buffer supplemented with phenylmethanesulfonyl fluoride (PMSF, Beyotime). The cellular extract was incubated for $30 \mathrm{~min}$ on ice and then subjected to centrifugation at $12000 \times \mathrm{g}$ for $15 \mathrm{~min}$ at $4^{\circ} \mathrm{C}$. The supernatant was collected, and the protein concentration was quantitated by BCA reagent kit (Beyotime) using bovine serum albumin (BSA) as a standard. Equal amounts of the protein samples $(50 \mu \mathrm{g})$ were separated by electrophoresis on a $10 \%$ sodium dodecyl sulfatepolyacrylamide gel and transferred to a polyvinylidene fluoride (PVDF) membrane (Bio-Rad, CA, USA). After blocking with non-fat dry milk at room temperature for $2 \mathrm{~h}$, the PVDF membrane was incubated overnight with antibodies $(1: 1000)$ at $4^{\circ} \mathrm{C}$. Rabbit monoclonal antiPCNA, anti-vimentin, anti-N-cadherin, anti- $\beta$-actin, and anti-phospho-Akt, Ser473 were purchased from Cell Signaling Technology (Devers, MA, USA). Rabbit monoclonal anti-phospho-ERK1/2, anti-phospho-Akt (Thr308), mouse monoclonal anti-ERK1/2, and anti-Akt were purchased from Millipore (Billerica, MA, USA). Rabbit monoclonal anti-integrin- $\beta 1$ and anti-integrin- $\alpha 5$ were obtained from Abcam. Rabbit monoclonal antiMMP-2 and anti-MMP-9 were ordered from Sanyin Technology (Wuhan, Hubei, China). After washing with Tris-Buffered Saline Tween (TBST)-20, the membrane was incubated with secondary goat anti-rabbit or goat anti-mouse IgG (1:1000, ZSGB-BIO, Beijing, China) at room temperature for $1 \mathrm{~h}$. After three times of washing with TBST, the membrane was developed by enhanced chemiluminescence reagents (Millipore, MA, USA). Quantification was performed by densitometric analysis using Quantity One software (Bio-Rad).

\section{Proliferation assay}

HTR-8/SVneo cells were seeded in triplicate at $1 \times 10^{3}$ cells/well into 96-well microplates containing $100 \mu \mathrm{l}$ RPMI with $10 \%$ FBS and exposed to different concentrations of BPA for $48 \mathrm{~h}$. Cell proliferation was measured using a EdU imaging kit (RibBio, Guangdong, China). The number of EdU-positive cells was counted in five different fields (up, down, left, right, and middle) in each well.

\section{Flow cytometry analysis}

Cell viability and cell cycle analyses were performed by flow cytometry using a BD FACS Vantage SE Cell Sorter (Becton-Dickinson, CA, USA), with a minimum 10,000 cells analyzed for each sample. The cell population of interest was gated on the basis of the forward- and side-scatter properties. Cut-off values (i.e., vertical and horizontal lines on the resulting scatter plots) were designated based on the autofluorescence of control cells. The data were analyzed using BD FACS Diva software (Becton-Dickinson). The results are expressed in terms of the percentage relative to controls.

\section{Scratch assay}

HTR-8/SVneo cells were plated in 6-well plates containing $2 \mathrm{ml}$ culture medium for $12-24 \mathrm{~h}$. The confluent cells were used to generate a wound by scraping off the cells with a sterile pipet tip. The cells were then incubated in the absence or presence of different concentrations of BPA for $48 \mathrm{~h}$ and photographed after an additional $24 \mathrm{~h}$ and $48 \mathrm{~h}$ culture. DMSO ( $0.1 \%$ in medium) was used as a control for BPA treatments. At each of two time points, unattached cells were removed before photographing by removing the existing medium. The scratch width was calculated based on three replicates and analysis were carried out by blinded observers [30].

\section{Transwell cell migration assay}

Cell migration assays were performed using uncoated Transwell insertsfitted with Corning membranes $(8 \mu \mathrm{m}$ pore size; Corning, Bedford, MA, USA) as described [31]. Briefly, HTR-8/SVneo cells were incubated in the absence or presence of different concentrations of BPA for $48 \mathrm{~h}$. Then $1 \times 10^{4}$ cells $/ 300 \mu \mathrm{l}$ of RPMI without FBS were plated in the upper chamber of each Transwell insert; the lower chambers contained $800 \mu \mathrm{l}$ RPMI supplemented with $10 \%$ FBS. After $24 \mathrm{~h}$ culture, the cells in the upper chambers were removed by gentle swabbing. Cells attached to the membrane were fixed with ice-cold methanol for $30 \mathrm{~min}$ and stained with hematoxylin. The membrane was excised from each filter and mounted upside down on a clean glass slide. Cell migration index was determined by counting the number of stained cells in five randomly chosen fields from each membrane. Cell migration was tested in duplicate cultures and on three independent occasions.

\section{Villous explants and BPA administration}

The use of the placenta tissues was approved by the Ethics Committee of Chongqing Medical University. Placental tissues at 6-8 weeks were obtained from women undergoing elective termination of pregnancy with gestational sac and original cardiovascular pulsation. Placental tissue was placed in ice-cold Dulbecco's Modified Eagle's Medium/F12 (DMEM/F12) medium (Life Technologies) with $100 \mu \mathrm{g} / \mathrm{ml}$ streptomycin and 100 $\mathrm{U} / \mathrm{ml}$ penicillin and processed within $2 \mathrm{~h}$ of collection. The tissues were washed in sterile phosphate-buffered saline (PBS) and dissected to remove endometrial tissue and fetal membranes. Small fragments of placental villi were teased apart and placed on a transparent 12-well plate pre-coated 
with diluted Matrigel (1:19 in DMEM; Corning) and polymerized at $37^{\circ} \mathrm{C}$ for $30 \mathrm{~min}$. Explants were cultured under $3 \%$ oxygen pressure and in DMEM supplemented with $100 \mu \mathrm{g} / \mathrm{ml}$ streptomycin, $100 \mathrm{U} / \mathrm{ml}$ penicillin and $20 \% \mathrm{FBS}$, with BPA $\left(5 \times 10^{-5} \mathrm{M}\right)$ or $\operatorname{DMSO}(0.1 \%$, as control group). Villous outgrowth was photographed every $24 \mathrm{~h}$. The migration distance and the outgrowth area were calculated using Photoshop (Adobe, San Jose, CA, USA). Three separate experiments were performed in triplicate $(\mathrm{N}=9)$.

\section{Primary EVTs extraction and culturing}

Primary EVT extraction was performed according to the protocol of Male et al. [32]. Briefly, the placenta villi were washed by PBS and digested with pre-warmed trypsin solution. Tissue suspension were placed on a $37^{\circ} \mathrm{C}$-heat block and stirred with a magnetic stirrer for about $10 \mathrm{~min}$. The digested tissues were filtered by 100 $\mu \mathrm{m}$ and $40 \mu \mathrm{m}$-bore diameter's filters (Corning). The filtrate was centrifuged for $5 \mathrm{~min}$ at $3000 \mathrm{rpm} / \mathrm{min}$. Eight $\mathrm{ml}$ lymphoprep was added into the $15-\mathrm{ml}$ centrifuge tube. The blown cell pellet was re-suspended in $5 \mathrm{ml}$ Ham's F12 medium and gently added onto the prepared lymphoprep. The tube was centrifuged for $20 \mathrm{~min}$ at $4000 \mathrm{rpm} / \mathrm{min}$. The cells were collected at the interface and washed with $15 \mathrm{ml}$ Ham's F12 medium. The suspension was then centrifuged for $5 \mathrm{~min}$ at $3500 \mathrm{rpm} / \mathrm{min}$. The cell pellet was re-suspended in $3 \mathrm{ml}$ Ham's F12 medium to remove placental macrophages and incubated in 6-well plates for $20 \mathrm{~min}$ at $37^{\circ} \mathrm{C}$. Finally, non-adherent cells were collected and seeded in the culture dish pre-coated with fibronectin (Corning) in medium containing 20\% FBS.

\section{Real-time quantitative polymerase chain reaction ( $R T-q P C R)$}

Total cellular RNA was extracted using Trizol (TaKaRa, Dalian, China). A total of $3 \mu \mathrm{g}$ of total RNA was subjected to reverse transcription by M-MLV reverse transcriptase (TaKaRa). The primers are shown in Table 1. RT-qPCR was performed using a SYBR Green Realtime PCR Master Mix kit (TaKaRa) under the following condition: initial pre-incubation at $95^{\circ} \mathrm{C}$ for $30 \mathrm{~s}$, followed by 39 cycles at $95^{\circ} \mathrm{C}$ for $5 \mathrm{~s}$ and $60^{\circ} \mathrm{C}$ for $30 \mathrm{~s}$. The relative mRNA levels of ITGB1,CDH2, VIM and MMP-9 were analyzed using the $2^{-\Delta \Delta C t}$ method.

\section{Immunofluorescence staining}

Cells were seeded on coverslips in 24-well plates containing $1 \mathrm{ml}$ medium. Cells were fixed in cold methanol (100\%) for $20 \mathrm{~min}$, followed by blocking in $1 \%$ BSA in PBS for $60 \mathrm{~min}$. Primary antibody (anti$\mathrm{N}$-cadherin, anti-vimentin, anti-integrin- $\beta 1$, or antiintegrin- $\alpha 5,1: 200)$ was incubated with cells in $1 \%$
BSA in PBS overnight at $4^{\circ} \mathrm{C}$ followed by addition of fluorescein isothiocyanate (FITC)-conjugated or Cy5conjugated secondary antibodies (1:1000, Beyotime) for $60 \mathrm{~min}$ at room temperature. The cells were mounted in Vectashield medium containing DAPI (Beyotime). Images were obtained using a fluorescence microscope (Olympus, Tokyo, Japan).

\section{siRNA transfection}

HTR-8/SVneo cells were transiently transfected with small interfering RNA (siRNA) sequences using HiPerFect reagent (Qiagen, Hilden, NRW, German) according to the manufacturer's protocol. The sequence of ITGB1 siRNAs and scrambled control (GenePharma, Shanghai, China) was shown in Table 2. After $48 \mathrm{~h}$ of transfection, RT-qPCR and western blot assays were used to measure the knockdown efficiency.

\section{Immunohistochemistry}

Mouse placental tissues were fixed overnight in 4\% paraformaldehyde (v/v). Fixed tissues were dehydrated in a graded series of ethanol, infiltrated with xylene and embedded in paraffin wax. Paraffin sections were prepared at the thickness of $5 \mu \mathrm{m}$ and rehydrated in a graded alcohol series. Immunohistochemistry was carried out with the rabbit antibody kit (ZSGB-BIO). Briefly, antigen retrieval was achieved by placing the sections in sodium citrate buffer for $10 \mathrm{~min}$ at room temperature, followed by $15 \mathrm{~min}$ at $100^{\circ} \mathrm{C}$ in a microwave oven. Endogenous peroxidase was inhibited by incubation with $3 \%$ hydrogen peroxide for 10 $\mathrm{min}$ at room temperature. Sections were pre-incubated with $10 \%$ goat serum for $30 \mathrm{~min}$ at $37^{\circ} \mathrm{C}$ and then incubated with primary antibody $(1: 200)$ anti-integrin- $\beta 1$ and antiintegrin- $\alpha 5$ at $4{ }^{\circ} \mathrm{C}$ overnight. On the following day, sections were washed in PBS and incubated with biotinylated secondary antibody (ZSGB-BIO) for $30 \mathrm{~min}$ at $37^{\circ} \mathrm{C}$ and then with streptavidin-conjugated horseradish peroxidase (ZSGB-BIO) for $30 \mathrm{~min}$ at $37^{\circ} \mathrm{C}$. Immunoreactivity was detected using the DAB substrate kit (Boster, Wuhan, China) and was visualized as brown staining. The sections were subsequently stained with hematoxylin (Nanjing JianCheng Bioengineering Institute, Nanjing, China).

\section{Statistical analysis}

Results of densitometric analysis, cell counts and migration length are expressed as fold change or the percent variationcompared with the control. GraphPad Prism 5.0 was used for statistical analysis. Differences between groups were assessed by one-way ANOVA followed by Tukey's multiple comparisons test. All experiments were independently repeated at least three times. The results were considered significantly different at $P<0.05$. 


\section{Abbreviations}

BPA, bisphenol A; EVT, extravillous trophoblast; MMP, matrix metalloproteinases; ECM, extracellular matrix; TGC, trophoblast giant cells; PCNA, proliferating cell nuclear antigen; MAPK, mitogen-activated protein kinase; PI3K, phosphatidylinositol-3-kinases.

\section{Author contributions}

The main experimental design: Yubin-Ding; Performed the experiments: Xi Lan and Jun Zhang; Analyzed the data: Li-Juan Fu, Xue Zhang and Hui-Jie Zhang; Contributed reagents: Ming-Fu Ma, Xue-Mei Chen, Jun-Lin He, Lian-Bing Li and Ying-Xiong Wang; Writing the manuscript: Xi Lan, Yubin-Ding and XueQing Liu. All the authors approved the final version.

\section{CONFLICTS OF INTEREST}

The authors declare that they have no conflict of interest.

\section{FUNDING}

This work was supported by the National Natural Science Foundation of China (grant numbers 81370731, 81671493, and 31571190), open funding by the Chongqing Institute for Family Planning (grant number 1201), the Natural Science Foundation of Chongqing (grant number cstc2016jcyjA0247), the foundation of Chongqing Education Committee (grant number KJ130309, Yujiaoren2014-47), and the Excellent Young Scholars of Chongqing Medical University (grant number CQYQ201302).

\section{REFERENCES}

1. Chevrier J, Gunier RB, Bradman A, Holland NT, Calafat AM, Eskenazi B, Harley KG. Maternal urinary bisphenol a during pregnancy and maternal and neonatal thyroid function in the CHAMACOS study. Environ Health Perspect. 2013; 121: 138-44. doi: 10.1289/ehp.1205092.

2. Maffini MV, Rubin BS, Sonnenschein C, Soto AM. Endocrine disruptors and reproductive health: the case of bisphenol-A. Mol Cell Endocrinol. 2006; 254-255: 179-86. doi: 10.1016/j.mce.2006.04.033.

3. Vandenberg LN, Chahoud I, Heindel JJ, Padmanabhan V, Paumgartten FJ, Schoenfelder G. Urinary, circulating, and tissue biomonitoring studies indicate widespread exposure to bisphenol A. Environ Health Perspect. 2010; 118: 1055 70. doi: 10.1289/ehp.0901716.

4. Ziv-Gal A, Flaws JA. Evidence for bisphenol A-induced female infertility: review (2007-2016). Fertil Steril. 2016; 106:827-56. doi: 10.1016/j.fertnstert.2016.06.027.

5. Hunt PA, Koehler KE, Susiarjo M, Hodges CA, Ilagan A, Voigt RC, Thomas S, Thomas BF, Hassold TJ. Bisphenol a exposure causes meiotic aneuploidy in the female mouse. Curr Biol. 2003; 13: 546-53.

6. Susiarjo M, Hassold TJ, Freeman E, Hunt PA. Bisphenol A exposure in utero disrupts early oogenesis in the mouse. PLoS Genet. 2007; 3: e5. doi: 10.1371/journal. pgen.0030005.

7. Varayoud J, Ramos JG, Bosquiazzo VL, Lower M, Munoz-de-Toro M, Luque EH. Neonatal exposure to bisphenol A alters rat uterine implantation-associated gene expression and reduces the number of implantation sites. Endocrinology. 2011; 152: 1101-11. doi: 10.1210/ en.2009-1037.

8. Farabollini F, Porrini S, Della Seta D, Bianchi F, DessiFulgheri F. Effects of perinatal exposure to bisphenol A on sociosexual behavior of female and male rats. Environ Health Perspect. 2002; 110: 409-14.

9. Forte M, Mita L, Cobellis L, Merafina V, Specchio R, Rossi S, Mita DG, Mosca L, Castaldi MA, De Falco M, Laforgia V, Crispi S. Triclosan and bisphenol a affect decidualization of human endometrial stromal cells. Mol Cell Endocrinol. 2016; 422: 74-83. doi: 10.1016/j.mce.2015.11.017.

10. Malassine A, Cronier L. Hormones and human trophoblast differentiation: a review. Endocrine. 2002; 19: 3-11. doi: 10.1385/ENDO:19:1:3.

11. Rajakumar C, Guan H, Langlois D, Cernea M, Yang K. Bisphenol A disrupts gene expression in human placental trophoblast cells. Reprod Toxicol. 2015; 53: 39-44. doi: 10.1016/j.reprotox.2015.03.001.

12. Wang ZY, Lu J, Zhang YZ, Zhang M, Liu T, Qu XL. Effect of Bisphenol A on invasion ability of human trophoblastic cell line BeWo. Int J Clin Exp Pathol. 2015; 8: 14355-64.

13. Morice L, Benaitreau D, Dieudonne MN, Morvan C, Serazin V, de Mazancourt P, Pecquery R, Dos Santos E. Antiproliferative and proapoptotic effects of bisphenol A on human trophoblastic JEG-3 cells. Reprod Toxicol. 2011; 32: 69-76. doi: 10.1016/j.reprotox.2011.05.003.

14. Ponniah M, Billett EE, De Girolamo LA. Bisphenol A increases BeWo trophoblast survival in stress-induced paradigms through regulation of oxidative stress and apoptosis. Chem Res Toxicol. 2015; 28: 1693-703. doi: 10.1021/acs.chemrestox.5b00093.

15. Benachour N, Aris A. Toxic effects of low doses of Bisphenol-A on human placental cells. Toxicol Appl Pharmacol. 2009; 241: 322-8. doi: 10.1016/j. taap.2009.09.005.

16. Spagnoletti A, Paulesu L, Mannelli C, Ermini L, Romagnoli $\mathrm{R}$, Cintorino M, Ietta F. Low concentrations of Bisphenol A and para-Nonylphenol affect extravillous pathway of human trophoblast cells. Mol Cell Endocrinol. 2015; 412: 56-64. doi: 10.1016/j.mce.2015.05.023.

17. Morck TJ, Sorda G, Bechi N, Rasmussen BS, Nielsen JB, Ietta F, Rytting E, Mathiesen L, Paulesu L, Knudsen LE. Placental transport and in vitro effects of Bisphenol A. Reprod Toxicol. 2010; 30: 131-7. doi: 10.1016/j. reprotox.2010.02.007. 
18. Jin H, Audus KL. Effect of bisphenol A on drug efflux in BeWo, a human trophoblast-like cell line. Placenta. 2005; 26: S96-S103. doi: 10.1016/j.placenta.2005.01.016.

19. Sieppi E, Vahakangas K, Rautio A, Ietta F, Paulesu L, Myllynen P. The xenoestrogens, bisphenol A and paranonylphenol, decrease the expression of the ABCG2 transporter protein in human term placental explant cultures. Mol Cell Endocrinol. 2016; 429: 41-9. doi: 10.1016/j. mce.2016.03.034.

20. Lee CK, Kim SH, Moon DH, Kim JH, Son BC, Kim DH, Lee CH, Kim HD, Kim JW, Kim JE, Lee CU. Effects of bisphenol A on the placental function and reproduction in rats. J Prev Med Public Health. 2005; 38: 330-6.

21. Susiarjo M, Sasson I, Mesaros C, Bartolomei MS. Bisphenol a exposure disrupts genomic imprinting in the mouse. PLoS Genet. 2013; 9: e1003401. doi: 10.1371/ journal.pgen.1003401.

22. Tachibana T, Wakimoto Y, Nakamuta N, Phichitraslip T, Wakitani S, Kusakabe K, Hondo E, Kiso Y. Effects of bisphenol A (BPA) on placentation and survival of the neonates in mice. J Reprod Dev. 2007; 53: 509-14.

23. Tait S, Tassinari R, Maranghi F, Mantovani A. Bisphenol A affects placental layers morphology and angiogenesis during early pregnancy phase in mice. J Appl Toxicol. 2015; 35: 1278-91. doi: 10.1002/jat.3176.

24. Cohen M, Bischof P. Factors regulating trophoblast invasion. Gynecol Obstet Invest. 2007; 64: 126-30. doi: 10.1159/000101734.

25. Husslein H, Haider S, Meinhardt G, Prast J, Sonderegger $\mathrm{S}$, Knofler M. Expression, regulation and functional characterization of matrix metalloproteinase- 3 of human trophoblast. Placenta. 2009; 30: 284-91. doi: 10.1016/j. placenta.2008.12.002.

26. Xu B, Nakhla S, Makris A, Hennessy A. TNF-alpha inhibits trophoblast integration into endothelial cellular networks. Placenta. 2011; 32: 241-6. doi: 10.1016/j. placenta.2010.12.005.

27. Gellersen B, Reimann K, Samalecos A, Aupers S, Bamberger AM. Invasiveness of human endometrial stromal cells is promoted by decidualization and by trophoblastderived signals. Hum Reprod. 2010; 25: 862-73. doi: 10.1093/humrep/dep468.

28. Zhu JY, Pang ZJ, Yu YH. Regulation of trophoblast invasion: the role of matrix metalloproteinases. Rev Obstet Gynecol. 2012; 5: e137-43.

29. Ptak A, Hoffmann M, Gruca I, Barc J. Bisphenol A induce ovarian cancer cell migration via the MAPK and PI3K/Akt signalling pathways. Toxicol Lett. 2014; 229: 357-65. doi: 10.1016/j.toxlet.2014.07.001.

30. Derouiche S, Warnier M, Mariot P, Gosset P, Mauroy B, Bonnal JL, Slomianny C, Delcourt P, Prevarskaya N, Roudbaraki M. Bisphenol A stimulates human prostate cancer cell migration via remodelling of calcium signalling. Springerplus. 2013; 2: 54. doi: 10.1186/2193-1801-2-54.
31. Ma XF, Zhang J, Shuai HL, Guan BZ, Luo X, Yan RL. IKKbeta/NF-kappaB mediated the low doses of bisphenol A induced migration of cervical cancer cells. Arch Biochem Biophys. 2015; 573: 52-8. doi: 10.1016/j.abb.2015.03.010.

32. Zhang KS, Chen HQ, Chen YS, Qiu KF, Zheng XB, Li GC, Yang HD, Wen CJ. Bisphenol A stimulates human lung cancer cell migration via upregulation of matrix metalloproteinases by GPER/EGFR/ERK1/2 signal pathway. Biomedicine \& Pharmacotherapy. 2014; 68: 1037 43. doi: 10.1016/j.biopha.2014.09.003.

33. Zhang XL, Liu N, Weng SF, Wang HS. Bisphenol A Increases the Migration and Invasion of Triple Negative Breast Cancer Cells via Oestrogen-related Receptor Gamma. Basic Clin Pharmacol Toxicol. 2016; 119:389-95. doi: 10.1111/bcpt.12591.

34. Onogi A, Naruse K, Sado T, Tsunemi T, Shigetomi H, Noguchi T, Yamada Y, Akasaki M, Oi H, Kobayashi H. Hypoxia inhibits invasion of extravillous trophoblast cells through reduction of matrix metalloproteinase (MMP)-2 activation in the early first trimester of human pregnancy. Placenta. 2011; 32: 665-70. doi: 10.1016/j. placenta.2011.06.023.

35. Chen CP. Placental villous mesenchymal cells trigger trophoblast invasion. Cell Adh Migr. 2014; 8: 94-7.

36. Peng L, Xing X, Li W, Qu L, Meng L, Lian S, Jiang B, Wu J, Shou C. PRL-3 promotes the motility, invasion, and metastasis of LoVo colon cancer cells through PRL-3integrin beta1-ERK1/2 and-MMP2 signaling. Mol Cancer. 2009; 8: 110. doi: 10.1186/1476-4598-8-110.

37. Louwen F, Muschol-Steinmetz C, Reinhard J, Reitter A, Yuan J. A lesson for cancer research: placental microarray gene analysis in preeclampsia. Oncotarget. 2012; 3: 759-73. doi: 10.18632/oncotarget.595.

38. Shi T, Zhao C, Li Z, Zhang Q, Jin X. Bisphenol a exposure promotes the migration of NCM460 cells via estrogen receptor-mediated integrin beta1/MMP-9 pathway. Environ Toxicol. 2016; 31: 799-807. doi: 10.1002/tox.22090.

39. Caswell PT, Vadrevu S, Norman JC. Integrins: masters and slaves of endocytic transport. Nature Reviews Molecular Cell Biology. 2009; 10: 843-53. doi: 10.1038/nrm2799.

40. Tait S, Tassinari R, Maranghi F, Mantovani A. Toxicogenomic analysis of placenta samples from mice exposed to different doses of BPA. Genom Data. 2015; 4: 109-11. doi: 10.1016/j.gdata.2015.04.004.

41. Vandenberg LN, Hauser R, Marcus $M$, Olea N, Welshons WV. Human exposure to bisphenol A (BPA). Reprod Toxicol. 2007; 24: 139-77. doi: 10.1016/j. reprotox.2007.07.010.

42. Watson ED, Cross JC. Development of structures and transport functions in the mouse placenta. Physiology (Bethesda). 2005; 20: 180-93. doi: 10.1152/ physiol.00001.2005.

43. Adamson SL, Lu Y, Whiteley KJ, Holmyard D, Hemberger M, Pfarrer C, Cross JC. Interactions between trophoblast 
cells and the maternal and fetal circulation in the mouse placenta. Dev Biol. 2002; 250: 358-73.

44. Cross JC, Simmons DG, Watson ED. Chorioallantoic morphogenesis and formation of the placental villous tree. Ann N Y Acad Sci. 2003; 995: 84-93.

45. Graham CH, Hawley TS, Hawley RG, MacDougall JR, Kerbel RS, Khoo N, Lala PK. Establishment and characterization of first trimester human trophoblast cells with extended lifespan. Exp Cell Res. 1993; 206: 204-11.

46. Hoffmann P, Saoudi Y, Benharouga M, Graham CH, Schaal JP, Mazouni C, Feige JJ, Alfaidy N. Role of EG-VEGF in human placentation: Physiological and pathological implications. J Cell Mol Med. 2009; 13: 2224-35. doi: 10.1111/j.1582-4934.2008.00554.x.

47. Beristain AG, Narala SR, Di Grappa MA, Khokha R. Homotypic RANK signaling differentially regulates proliferation, motility and cell survival in osteosarcoma and mammary epithelial cells. J Cell Sci. 2012; 125: 943-55. doi: $10.1242 /$ jcs.094029.

48. Male V, Gardner L, Moffett A. Isolation of cells from the feto-maternal interface. Curr Protoc Immunol. 2012; Chapter 7: Unit 740 1-11. doi: 10.1002/0471142735. im0740s97. 